УДК 371.315:811.111

DOI: $10.15421 / 382008$

A. Kyrychenko, N. Safonova

А. О. Кириченко, Н. А. Сафонова

А. А. Кириченко, Н. А. Сафонова

Oles Honchar Dnipro National University

Дніпровський начіональний університет імені Олеся Гончара

Днепровский национальный университет имени Олеся Гончара

\title{
DIDGITALIZATION OF FOREIGN LANGUAGE TEACHING IN HIGHER EDUCATIONAL INSTITUTIONS
}

\section{ДІДЖИТАЛІЗАЦІЯ НАВЧАННЯ ІНОЗЕМНОЇ МОВИ У ВИЩІЙ ШКОЛІ}

\section{ДИДЖИТАЛИЗАЦИЯ ПРЕПОДАВАНИЯ ИНОСТРАННОГО ЯЗЫКА В ВЫСШЕЙ ШКОЛЕ}

Education is a determining factor in the socio-economic development of the information society. Digitalization is gradually reforming all spheres of life, and most actively, the educational system. Today, there is a clear need to learn foreign languages, and the use of digital tools in teaching is a new trend in education. Educational technologies go beyond the usual multimedia tools, as the current generation of students has challenged educators to use cutting-edge channels of communication with young people to co-create educational content on existing networks. Gamification of tasks, virtual classrooms, online courses have become a reality, so the teacher is obliged to engage them as effectively as possible in the educational process in higher educational institutions.

Keywords: digital tools, digitalization, teaching, technology.

Освіта є вирішальним чинником розвитку інформаційного суспільства. Діджиталізація заповнюс усі сфери життя, а особливо активно - освітню систему. Сьогодні існус потреба вивчати іноземні мови і використання цифрових засобів у викладанні с новою тенденцією в освіті. Освітні технології виходять за межі звичайних мультимедійних засобів. Сучасне покоління студентів має освітян, перед якими постає проблема використовувати передові комунікаційні технології, щоб створити освітній контент в існуючих соціальних мережах. Геймифікація завдань, віртуальні класи, онлайн курси стали реальністю. Отже, викладачі змушені залучати студентів вищих навчальних закладів у навчальний процес якнайефективніше.

Ключові слова: цифрові засоби, діджиталізація, навчання, технології.

Образование является решающим фактором развития информационной среды. Диджитализация наполняет все сферы нашей жизни, а особенно - образовательную систему. Сегодня есть потребность изучать иностранные языки и использование цифровых технологий в преподавании является основной тенденцией в образовании. Образовательные технологии выходят за пределы обычных мультимедийных средств. Современное поколение студентов имеет преподавателей, перед которыми встает проблема использовать передовые цифровые технологии, чтобы создать образовательный контент в социальных сетях. Геймификация заданий виртуальные классы, онлайн курсы стали реальностью. Перед преподавателями возникает задание вовлекать студентов высших учебных заведений в учебный процесс наиболее эфективно.

Ключевые слова: цифровые средства, диджитализация, обучение, технологии.

Various digital tools have always been considered a feature of education and language education in particular. It is crucial to make sure that the available technologies are

(C) Budilova O., Bilova A., 2020 
used effectively. Therefore, it is important to identify priority areas for implementing information and communication technologies (ICT) and strategies for developing media literacy for teachers and students, as well as outlining the perspectives and benefits of digitalizing a new educational paradigm.

We are confronted with the following questions: Does the digitalization of education improve learning achievements, does it facilitate the life of an educator, can ICT replace traditional forms of language learning, can learning be a game, or perhaps new educational platforms only distract from the real learning process, or are new ones Does technology open up the world of education to learners, or is the current generation of students more sensitive to information noise? The aim of our article is to answer all these questions.

It should be stated that modern students require much more than traditional academic training, so the topic of the relationship between cognitive (IQ) and emotional (EQ) intelligence has been actively discussed in the last decade as well as the enhancing of this development with the help of digital tools used for language education.

Active use of information and communication technologies in the educational process of higher education significantly accelerates the exchange of knowledge and experience not only between individuals, but also between generations. Digital tools, by improving the quality of learning and language education in particular, enable learners to adapt more quickly to social change. The active introduction of these technologies into higher education is an important factor in creating a new education system that meets the requirements of the information society.

Social networking is an applied technology that can make learning a foreign language a more enjoyable experience with minimal stress. Moreover, the integration of technology into education gives the user more confidence and provides practical use of the language with its visual, audio and kinetic perception through portable devices. It is not always easy to motivate students, as this task involves many linguistic and psycho-sociological factors.

Jay Ackerman explored the use of the blog as a means of motivating students to develop productive foreign language skills, namely writing [3]. The use of ICT by the teacher has also changed the role of the teacher himself, thus transitioning from lecturer to coordinator of the learning process, helping the student to become more independent. It can also be concluded that the use of ICT has also become more conducive to more traditional approaches, such as project-based, competency-based or task-based learning, as it has expanded these approaches and helped students to formulate a range of learning strategies and styles that foster autonomy and provide individualized learning on selected and proposed platforms.

ICT and digitalization advocates emphasize that Computer-Assisted Language Learning (CALL) develops and consolidates student autonomy. Cynthia Lee points out that changing the roles of teacher and student is a critical factor in the success of the ICT experience. From now on, the teacher does not have to be the sole resource of knowledge, and the student has a new role to play, as every learner assumes full responsibility for studies [4].

The more the teacher uses learning technologies, the greater the opportunities for discovery learning, student focus, and individualization of learning are. Another way to develop autonomy is through a web quest. Web quests are designed to optimize time, focus on how to use the information, not just look for it, but also aim to support the student's thinking at the level of analysis, synthesis and evaluation.

As noted by David Smith and Eric Baber, the result of this task is the presentation of a study that requires the student to make an effort and use all the previously acquired skills and knowledge. Thus, the level of achievement of the student increases and his / her independence in learning is enhanced [6]. It should be understood that the ICT 
environment should not be considered as a universal miracle tool for any student who wants to master language and speech competences. Students have different learning styles, and for a particular group, learning in an environment where the influence of the teacher (teacher-dominated classroom) is more dominant will remain.

ICT remains a leader among other methods of ensuring authentic foreign language communication between native speakers and its speakers. The ease, speed and accessibility of ICT communication is optimal in the context of students' limited time and financial resources. Audio or video communication is about sharing information, discussing issues, and engaging in cultural and linguistic exchange. By immersing in such an information stream, students can obtain the necessary language environment, apply and comprehensively develop listening, reading, writing and speaking skills in a real life context. An important advantage is to provide a truly authentic context from other users presented in the form of images, texts, audio recordings, podcasts, blogs of both native speakers, and those who study the language, which is an additional motivation for learning.

When students are aware that their blog or podcast will have a potential native speaker, they are more likely to actively produce other language content improving their language skills. In addition, when students write or speak to a wide international audience, they strive for greater excellence, which means they are ready to work on skills such as pronunciation.

Another benefit of implementing digital tools is the involvement of all channels of perception, the so-called multisensory. Information can be presented in many formats, presenting audio, text, images, or video, thus matching students' learning styles.

Michael Evans notes the disadvantage of ICT, since the availability and availability of authentic content is not always an advantage, given that material created for native speakers may be considered as «difficult» for teachers and students, and the topic of such material may closely to interact with a culture with which the student is unfamiliar [2].

Robert Blake points out that teacher with little experience in ICT use may have the mistaken belief that the usual transformation of a task into a CALL format will be guaranteed to be successful for students. Therefore, any task without adequate pedagogical planning and development (technologically supported or not) will lead to unsatisfactory results, even if it is attractive in terms of multimedia [1].

Gamification and motivation are closely connected. Joey Lee, Jessica Hammer, and Christina Muntean are convinced that, provided it is properly used, gamification in the learning process is a positive means of student motivation [5]. Such use of game elements in normal situations to some extent converts the usual tasks in the game and aims to combine the external and internal motivation of the student to involve him in the learning process. The analysis of the literature shows that the topic is relevant in modern education. At the same time, the problem is not sufficiently solved, as the number of newest technologies is increasing every year.

Educators agree on the need to integrate ICT into the educational process of higher education institutions. The prerequisite for successful involvement of such a voluminous resource, such as information and communication technologies, should be the professional training of teachers who operate the new learning technology. Every participant in the training - from the administration to the teacher and the student - must have information and media literacy and be familiar with the use of the latest technologies.

The reforms taking place in the Ukrainian education system show that traditional views on education are consistently changing, enabling effective learning through the widespread use of new digital tools. The most significant problem in the use of ICT in the educational field is the lack of knowledge or inability of teaching staff to use the 
latest technologies at work. This impedes to some extent the educational process and the working cycle of the higher education institution.

In the age of mobile applications, foreign language teachers are beginning to see them as a tool that can be used for academic purposes, to keep in touch with students and generate contemporary assignments for them, because in the Instagram era, anyone can easily become a creator of digital content, taking on the role of writer, artist or photographer.

The drawback is that many students still have limited access to English, and many are interested in learning about the culture but are not able to travel and immerse in the language environment. In addition, such content can be a good example of cultural cooperation.

Advantages of computer learning are quite obvious: multimedia, increased motivation, interest of students, wide choice of information, mostly free access to it, independent coordination by the teacher of the educational process, the ability to communicate with native speakers, acquaintance with the culture of the language being taught, providing students wide access to information sources, students' ability to self-assess their completed tasks and track the progress of academic achievement, the implementation of individual and differentiated learning outcomes students' education, formation of their professional competence and competence.

Consideration should also be given to the negative aspects of the use of social networks, such as the overuse of these networks by students, as well as the destruction of subordination of relations at the teacher-student level. By encouraging students to use Instagram as an educational tool through the exchange of ideas and opinions between students and the teacher you can create a unique educational process that is reminiscent of the game, but has an important educational mission.

In the age of total digitalization, the positive impact of the use of information and communication technologies in education is obvious, but the use of digital tools without careful planning and clearly defined goals will be an ineffective task, and sometimes even a waste of time and effort. ICT tools such as interactive videos, the Internet, or e-mail can help a student acquire linguistic skills, establish linguistic contact with other users, broaden their outlook, become familiar with other cultures, values, and modern lifestyles in English or native languages foreign language of communication. ICT-based teaching should aim to create liveliness and interactivity in English classes. A challenge or even a barrier to the implementation of ICT in the educational process is a certain bias.

Therefore, the following questions arise: are digital tools really delivering visible results, improvements and optimization of foreign language teaching? Is ICT about being visually beautiful or functionally useful? Is the use of ICT in English lessons a means of introducing positive change in the learning process and providing an environment for diverse and productive language learning?

Today, we see a great need for continuous improvement of the professional level and the acquisition of new skills, and the concept of lifelong learning is actively included in the educational paradigm of Ukrainian society. The use of digital tools in the system of foreign language teaching and learning is an adequate response to the current challenges of the Ukrainian information society. ICT remains a leader among other methods of ensuring authentic foreign language communication.

A significant advantage of the 21 st century is the availability of a virtual environment that allows you to go beyond the space-time frame, giving its users the opportunity to authentically communicate and discuss with representatives of different cultures current issues of today. With this in mind, it should not be forgotten that the Internet is only an 
auxiliary technical training tool, and for optimal results it is necessary to integrate its use in the learning process.

Considering the use of Internet resources in foreign language learning, we can distinguish the following positive aspects of its implementation: increases students 'motivation to study, enables the teacher to individualize the educational process, promote the development of students' independence, encourage the use of information and develop media literacy, increases the cultural and linguistic awareness of philological students, thanks to a wide choice of authentic materials of any subject and level of complexity, improves linguistic competences, provides upto-date material that corresponds to the trends in the educational sphere, and also communicates with the interests and needs of students, offers creating your own content.

There is no doubt that Internet technologies provide new opportunities for students to master a foreign language, in particular the formation of a single linguistic space, interactivity of the learning process and multimedia. This means using not only text, hypertext and graphic materials, but also audio and video files, animations, activity of all channels of perception of information when working with various multimedia Internet resources.

There are currently many sites on the Internet that can be integrated into the educational process. This raises the problem of finding the right site because even with advanced search engines, search results can show hundreds or even thousands of site links of different nature. The peculiarities of realization of teaching methods of students with the use of new information technologies with the purpose of mastering their key socio-cultural skills by providing individualization of the pace of learning, monitoring the formation of socio-cultural knowledge, organization of independent educational and cognitive activity were discussed.

The study does not cover all aspects of the problem. Areas for further research may be development of a methodology for the thorough selection of modern Internet technologies that can be used for teaching foreign languages in higher educational institutions, determining the potential and methods of using artificial intelligence in the educational environment in the teaching of foreign languages.

\section{References}

1. Blake, R. J. (2008). Brave New Digital Experience. Hong Kong: The Chinese Classroom: Technology and Foreign Language Learning. Washington, D.C: Georgetown University Press.

2. Evans, M. et al (2009). Foreign Language Learning with Digital Technology. (Education and Digital Technology) London: Continuum International Publishing Group.

3. Jay D.A. (2006). Motivating for writing through blogs. A Master thesis submitted to the Graduate College of Bowling Green State University. URL: http:// etd.ohiolink.edu].

4. Lee, C. (2005). Web-based Teaching and English Language Teaching: A Hong Kong

University Press of Hong Kong].

5. Lee, J. J., \& Hammer, J. (2011). Gamification in education: What, how, why bother? Academic Exchange Quarterly, 15(2). In Muntean, C. (2011). Raising engagement in e-learning through gamification. Retrieved Apr 4, 2013. URL: http://www.icvl.eu/2011/ $\mathrm{disc/icvl/documente/pdf/met/ICVL}$ ModelsAndMe thodologies_paper42.pdf]

6. Smith, D. \& Baber, E. (2005). Teaching English with Information Technology. London: Modern English Publishing Ltd. 